\title{
Prevalence of Pressure Injuries and Risk Factors in Long-Term Surgical Procedures
}

\section{Uzun Süren Cerrahi Girişimlerde Basınç Yaralanması Prevalansı ve Risk Faktörleri}

(i) Cemile AKAN1, id Yazile YAZICI SAYIN²

'Bezmialem Vakıf University Hospital, Nursing Services Directorate, Turkey

${ }^{2}$ Bezmialem Vakıf University Faculty of Health Sciences, Nursing Department, İstanbul, Turkey

\section{ABSTRACT}

Objective: To determine the risk factors and prevalence associated with intraoperative pressure injury (IPI) in surgical procedures lasting more than two hours, and to draw attention of surgical nurses to the prevention of IPI.

Methods: This cross-descriptive study included 170 patients in whom major surgical procedures were planned in a private foundation university hospital's orthopedics and general surgery departments between February 2017 and May 2018. The study was approved by the ethics committee and informed written permission was obtained from the institutions and volunteers. Data were collected by using Braden Risk Assessment Tool (BRAT) and literature based patient diagnosis form.

Results: The mean age of the participants was $47.72 \pm 22.20$ years, $55.9 \%$ were female and $44.1 \%$ were male. Of the participants, $81.8 \%$ underwent surgery in the supine position, with a mean surgery duration of $246.707 \pm 145.3$ minutes. Of the patients $24.1 \%$ developed stage I IPI. Forty-one (24.2\%) patients with pressure injury had a lower BRAT score $(18.434 \pm 6.621)$ than 129 (75.8\%) patients without pressure injury $(20.243 \pm 3.954), \quad(p=0.035)$. According to multivariate analysis, both preoperative additional nutritional requirement and low albumin level increased the risk of IPI by 2.4 fold ( $\mathrm{p}=0.038 ; 0.043$, respectively). Each one hour of prolongation in duration of surgery increased the risk of IPI by 1.007 times $(\mathrm{p}=0.002)$.

\section{ÖZ}

Amaç: İki saatten uzun süren cerrahi girişimlerde ameliyat sırasındaki basınç yaralanması (ASBY) ile ilişkili risk faktörlerini ve ASBY prevalansını belirlemek, ASBY'nin önlenmesine cerrahi hemşirelerin dikkatini çekmektir.

Yöntemler: Kesitsel-tanımlayıcı bir araştırma olarak özel bir vakıf üniversitesi hastanesinin ortopedi, genel cerrahi servislerinde, Şubat 2017-Mayıs 2018 tarihlerinde, 170 büyük cerrahi girişim planlanan gönüllü bireyin katılımı ile yapıldı. Etik kurul onayı ile kurum ve gönüllülerden bilgilendirilmiş yazılı izin alındı. Veriler Braden basınç yarası ölçeği ve literatüre dayalı hasta tanımlama formuyla toplandi.

Bulgular: Katılımcıların yaş ortalaması $47,72 \pm 22,20$ yıl idi, $\% 55,9$ 'u kadındı ve \%44,1'i erkekti. Katılımcıların \%81,8'i supine pozisyonunda ameliyat oldu, ameliyatın ortalama süresi $246,707 \pm 145,3$ dakikaydı. Hastaların \%24.1'inde evre 1 ASBY gelişmişti. Basınç yaralanması gelişen $41 \quad(\% 24,2)$ hastanın Braden risk puanı $(18,434 \pm 6,621)$ basınç yaralanması olmayan 129 hastadan $(\% 75,8)(20,243 \pm 3,954)$ daha düşüktü $(\mathrm{p}=0,035)$. Multivaryans analizine göre, ameliyat öncesi hem ek beslenme gereksinimi olmak, hem albümin düşüklüğü ASBY riskini 2,4 kat artırdı (sırasıyla $\mathrm{p}=0,038 ; 0,043$ ). Ameliyat süresinin her bir saatlik uzaması ASBY riskini 1.007 kat yükseltti $(\mathrm{p}=0,002)$.

*The research was presented as an oral presentation in English at the $3^{\text {rd }}$ International \& $11^{\text {th }}$ National Congress of Turkish Surgical and Operating Room Nurses ( $3^{\text {rd }}$ International $11^{\text {th }}$ National Congress of Turkish Surgical and Operating Room Nurses) held in Izmir-Çeşme on 3-6 October 2019.

Address for Correspondence: Yazile YAZICI SAYIN, Bezmialem Vakıf University Faculty of Health Sciences, Nursing Department, İstanbul, Turkey

E-mail: ysayin@bezmialem.edu.tr ORCID ID: orcid.org/0000-0002-5741-754X

Cite this article as: Sayın Yazıcı Y, Akan C. Prevalence of Pressure Injuries and Risk Factors in Long-Term Surgical Procedures. Bezmialem Science 2021;9(1):75-83. 
Conclusion: The risk of development of IPI is high in major surgical procedures. In determining the risk of IPI, the patient's nutritional deficiency, low albumin level, length of duration of surgery and BRAT score are important.

Keywords: Intraoperative period, pressure injury, risk factor, prevalence of pressure injury
Sonuç: Büyük cerrahi girişimlerde ASBY gelişme riski yüksektir. ASBY riskinin belirlenmesinde hastanın beslenme yetersizliği, albümin düşüklügü, ameliyat süresi uzunluğu ve Braden risk puanı önemlidir.

Anahtar Sözcükler: Ameliyat sırası dönem, basınç yarası, risk faktörü, basınç yarası prevalansı

\section{Introduction}

Intraoperative pressure injury (IPI) is one of the perioperative care problems that negatively affect the expected postoperative outcomes. This injury, which is seen within the first 48-72 hours after surgery, is a costly complication that may result in morbidity (1-3). Particular attention is paid to the "intraoperative process" in which the pressure injury emerges. In this process, many risk factors such as patient characteristics, surgery time and position affect the formation of pressure wounds (4-7).

It has been reported in the literature that the incidence of IPI varies between $2.8-12 \%$ depending on the type and duration of the surgery (8-10), and that the frequency is $8.5-39.5 \%$ in longterm surgical interventions (11-14). Studies conducted in Turkey report the prevalence of pressure injury in surgical patients between $8.9-36.4 \%$ (15-17).

Many studies draw attention to the length of surgery in the development of IPI $(13,18,19)$. Patient characteristics such as nutritional status, albumin level, body mass index (BMI) are also highlighted, especially in surgeries longer than two hours, and the importance of research is emphasized. In addition, the importance of patient preparation and skin care in long surgical interventions is emphasized $(4,20)$.

Although anesthesiologists are shown as the first responsible for positioning the patient on the operating table, anesthesiologists may not consider the risk of IPI or may be insufficient in this (21). However, the operating room nurse is expected to determine the internal and external risks of the patient according to the patient's position and reduce the risk of IPI with position support devices $(22,23)$. However, there is no ideal method to determine patients at risk of developing IPI (21). In this direction, the aim of the study was to determine the risk factors and prevalence of IPI in surgical interventions lasting more than two hours, and to draw the attention of surgical nurses to prevent IPI.

\section{Research Questions}

In surgical procedures lasting more than two hours;

- Are sociodemographic and some clinical features a risk factor for the development of IPI?

- Does the surgery time constitute a risk factor for IPI?

- Do preoperative vital signs (blood pressure, pulse, respiratory rate) constitute a risk factor for IPI?
- What is the risk of IPI in the assessment with the Braden Risk Assessment Tool (BRAT)?

- Are albumin value and nutritional problems a risk factor for IPI?

- Do the support materials used for the position and position given for surgery affect the formation of IPI?

\section{Method}

The research was a descriptive-cross-sectional study.

\section{Place and Time}

The study was carried out between June 2017 and May 2018 in a private foundation university hospital's orthopedics (bed capacity 41) and general surgery clinics (bed capacity 35 ).

\section{Universe and Sampling}

Power analysis was done for the sample. For this, the number of surgeries $(10,23-25)$ of the orthopedics and general surgery clinics in the last year was obtained from the hospital's database. Of this number, $19-20 \%$ consisted of major surgeries. In this case, the sample size was calculated as 170 according to the confidence level $(95 \%)$ and the acceptable error (5\%). Individuals were included in the study with a "purposeful sampling" according to the selection criteria.

Inclusion criteria:

- Being 18 years or older

- Surgery planned to last for at least two hours

- No pressure injury and no activity limitation before surgery

- Planning surgery under general anesthesia

- Volunteering to participate in research

- Being able to communicate

Exclusion criteria:

- In case of emergency surgery

- Planning small surgical intervention

- The dependent variable is IPI.

Independent variables are age, gender, chronic disease, habits, BMI, whether requiring special nutritional support, dehydration, 
low hemoglobin $(\mathrm{Hb})$ and low albumin level, hypotension, body temperature, heart rate, surgery time, position in the surgery, and the quality of position support tools.

\section{Data Collection Tools}

The data were collected using the Participant information form developed based on the literature $(3,4,23,26,27)$ and the BRAT.

Participant information form contains questions about age, gender, chronic illness, habits, BMI, whether requiring special nutritional support, dehydration, low $\mathrm{Hb}$ and/or albumin level, hypotension, body temperature, pulse, surgery time, position in the surgery, and quality of position support tools.

The BRAT was developed by a team including Bergestrom and Braden in 1987 to prevent pressure injury. It was reported that its specificity and sensitivity were between 64\% and 90\% (28). It was emphasized that the scale had satisfactory reliability when used by specialist nurses. Pressure injury risk factors of patients were taken into consideration in the scale (28). Its validity and reliability study in Turkish was made in 1998 by Pınar and Oğuz (29).

The BRAT consists of 6 sub-dimensions. These dimensions are; sensory perception (1-4 points), humidity (1-4 points), activity (1-4 points), mobility (1-4 points), nutrition (1-4 points), friction and tearing (1-3 points). The total score of the scale ranging from 6-23 is obtained by summing the sub-dimension scores. According to the total score, 6-10 points are considered to be very high-risk, $11-15$ points as high-risk, 16-19 points as moderate risk, and 20-23 points as low risk (28).

Although the BRAT has been suggested to have low sensitivity and moderate specificity for surgical patients, it is one of the most widely used scales $(21,30,31)$. The reason for preference in the presented study was that it was used as a common scale in all clinics of the institution where the study was conducted. It was thought that this situation would facilitate the initiation of applications in the data source hospital where the results would be shared.

\section{Collection of Data}

In the presented study, $80 \%$ of the data were collected by researchers and about $20 \%$ by clinical nurses who were informed about the research. Communication was made easy because the nurses also used the clinical forms in the clinic where they worked. Short interviews were conducted with the nurses to ensure mutual consensus on pressure injury staging information by the researchers. All evaluation of the forms was done by the researchers. Written consent was obtained from the patients who met the inclusion criteria after the purpose of the study was explained. Patient characteristics were determined with the "introductory (individual and clinical) information form" on the morning of the surgery. The BRAT skin diagnosis was made and the patient was sent to surgery. After the surgery, the operating room nurse was interviewed for the position during the surgery, the duration of the surgery, position support materials, and the presence of any injurious condition, and the operating room epicrisis was examined. The patient, who was sent from the operating room to the ward to determine IPI, was evaluated with the BRAT within the first 2-4 hours. The pressure injury conditions seen in the patient were shared with the team.

\section{Statistical Analysis}

The data were analyzed by using SPSS 15.0 package program. Statistical significance tests were chosen according to the distribution of the data. In this study, frequency, mean (mean) and standard deviation were used for descriptive statistics, chisquare $\left(\chi^{2}\right)$ test, Mann-Whitney U test, Kruskal-Wallis test, independent t-test, and multivariate and univariate analyzes were performed. The significance value was accepted as $\mathrm{p}=0.05$.

\section{Ethical Aspects}

The permission was obtained from the Clinical Research Ethics Committee of the relevant University Hospital for the research (Ethics committee permission no: 05.07.2017-11968-11/160), and institutional permission (could not be disclosed because it was stated that the name would not be specified at the time of publication) was obtained. Written informed consent was obtained from the participants.

\section{Results}

Table 1 shows the socio-demographic and some clinical characteristics of the participants. According to the characteristics of the patients in the preoperative period; the mean age of the participants was $47.72 \pm 22.20$ years, $52.9 \%$ of them were 51 years old or older, and $55.9 \%$ were women. Only $35.3 \%$ of the patients were smoking, $67.7 \%$ of the BMI was 18.5-24.9 $\mathrm{kg} / \mathrm{m}^{2}$ (within normal limits), 63.3\% were patients of general surgery clinic, $51.8 \%$ had chronic diseases. Of the participants, $97.1 \%$ were conscious patients. Of the patients, $25.3 \%$ had to take additional nutrition outside of the nutrition program. In addition, $12.4 \%$ of them had a Hb level of $13.5 \mathrm{~g} / \mathrm{dL}$ (the lowest $\mathrm{Hb}$ level of the patients was $13.5 \mathrm{~g} / \mathrm{dL}$ and the highest $\mathrm{Hb}$ level was $17.7 \mathrm{~g} / \mathrm{dL}), 24.7 \%$ of them had an albumin level $3.4 \mathrm{~g} / \mathrm{dL}$ or lower. However, blood pressure, respiratory status and body temperatures of the vast majority of the patients were within normal limits.

According to the operative period characteristics of the participants; $81.8 \%$ of the participants had surgery in the supine position. All of the patients were laid on a mattress on the operating table, pressure areas and body cavities were supported only with sheets and handmade pads.

IPI of stage I was detected in $24.2 \%$ of the patients in the coccyx and sacral region.

Table 2 includes the IPI status of the participants according to some sociodemographic characteristics. As the age of the patients increased, it was determined that the incidence of IPI increased, but this increase was not statistically significant ( $p>0.05)$. In this study presented, more IPI occurred in male patients than in female patients, but the difference was not statistically significant $(p>0.05)$. The mean surgery duration 


\begin{tabular}{|c|c|c|}
\hline Characteristics & n & $\%$ \\
\hline \multicolumn{3}{|l|}{ Age $^{*}$} \\
\hline $18-28$ & 19 & 11.2 \\
\hline $29-39$ & 28 & 16.5 \\
\hline $40-50$ & 33 & 19.4 \\
\hline$>51$ & 90 & 52.9 \\
\hline \multicolumn{3}{|l|}{ Gender } \\
\hline Female & 95 & 55.9 \\
\hline Male & 75 & 44.1 \\
\hline \multicolumn{3}{|l|}{ Smoking history } \\
\hline Smoker ${ }^{€}$ & 60 & 35.3 \\
\hline Not a smoker & 110 & 64.7 \\
\hline \multicolumn{3}{|l|}{ BMI } \\
\hline$<18.5 \mathrm{~kg} / \mathrm{m}^{2}$ & 13 & 7.6 \\
\hline $18.5-24.9 \mathrm{~kg} / \mathrm{m}^{2}$ & 115 & 67.7 \\
\hline $25.0-29.9 \mathrm{~kg} / \mathrm{m}^{2}$ & 42 & 24.7 \\
\hline \multicolumn{3}{|l|}{ Department } \\
\hline Orthopedics & 62 & 36.5 \\
\hline General surgery & 108 & 63.5 \\
\hline \multicolumn{3}{|l|}{ Chronic disease } \\
\hline Yes & 88 & 51.8 \\
\hline No & 82 & 48.2 \\
\hline \multicolumn{3}{|l|}{ Pre-operative consciousness } \\
\hline Conscious & 165 & 97.1 \\
\hline Unconscious & 5 & 2.9 \\
\hline \multicolumn{3}{|l|}{ Nutritional status } \\
\hline Normal diet & 127 & 74.7 \\
\hline Need nutritional support & 43 & 25.3 \\
\hline \multicolumn{3}{|l|}{ Hemoglobin* } \\
\hline $13.5 \mathrm{~g} / \mathrm{dL}$ & 21 & 12.4 \\
\hline $13.6-17.7 \mathrm{~g} / \mathrm{dL}$ & 149 & 87.6 \\
\hline \multicolumn{3}{|l|}{ Albumin } \\
\hline$\leq 3.4 \mathrm{~g} / \mathrm{dL}$ & 42 & 24.7 \\
\hline $3.5-5.5 \mathrm{~g} / \mathrm{dL}$ & 128 & 75.3 \\
\hline \multicolumn{3}{|l|}{ Blood pressure } \\
\hline $100-140 / 60-80 \mathrm{mmHg}$ & 130 & 76.5 \\
\hline$>140-90 \mathrm{mmHg}$ & 40 & 23.5 \\
\hline \multicolumn{3}{|l|}{ Pulse } \\
\hline $60-100 \mathrm{~min}$ & 159 & 93.5 \\
\hline$>100 \mathrm{~min}$ & 11 & 6.5 \\
\hline \multicolumn{3}{|l|}{ Preoperative temperature } \\
\hline $36-36.8^{\circ} \mathrm{C}$ & 169 & 99.4 \\
\hline \multicolumn{3}{|l|}{ Preoperative respiratory rate ${ }^{\Omega}$} \\
\hline $12-20 \mathrm{dk}$ & 161 & 94.7 \\
\hline \multicolumn{3}{|l|}{ Surgical position } \\
\hline Supine & 139 & 81.8 \\
\hline Prone or lateral & 31 & 18.2 \\
\hline \multicolumn{3}{|c|}{ Surgical position support materials } \\
\hline Mattresses/sheets and pads $\varnothing$ & 170 & 100.0 \\
\hline \multicolumn{3}{|l|}{ Postoperative pressure injury } \\
\hline Yes ** & 41 & 24.2 \\
\hline No & 129 & 75.8 \\
\hline \multicolumn{3}{|c|}{$\begin{array}{l}¥: \text { Mean age } 47.72 \pm 22.20, € \text { : only } 7(4.1 \%) \text { participants smoke more than one } \\
\text { pocket of cigarette a day, }{ }^{*} \text { Range: } 13.5 \mathrm{~g} / \mathrm{dL}-17.7 \mathrm{~g} / \mathrm{dL} \text {. } \\
\Omega \text { : Nine patients }(5.3 \%) \text { had a respiratory rate } \geq 21 / \mathrm{min} \text {. } \\
\emptyset \text { : Position support material made by the operating room nurse with cotton an } \\
\text { gauze } \\
\text { **Stage I pressure injury is a diffuse rash around the sacral and coccygea } \\
\text { regions that does not fade with pressure } \\
\text { BMl: Body mass index }\end{array}$} \\
\hline
\end{tabular}

$(211.00 \pm 132.83 / 165.32 \pm 83.27)$ of male patients was longer than that of females, and the difference was statistically significant $(\mathrm{p}=0.01)$ (Table 4).

Table 3 includes IPI according to the clinical characteristics of the participants. There was no statistically significant relationship between the patients' IPI and BMI, smoking history, and chronic disease history ( $p>0.05$ ) (Table 3$)$. However, the surgery durations of the patients with high and low BMI were shorter than those with normal BMI $(140.76 \pm 121.13 ; 156.42 \pm 67.67$; $201.13 \pm 118.15$, respectively) $(\mathrm{p}=0.034)$ (Table 4$)$.

It was observed that patients of general surgery clinic developed more IPI than orthopedic patients, and this difference was statistically significant $(\mathrm{p}=0.047)$ (Table 3$)$. The surgery duration in orthopedic patients was shorter than in patients of general surgery clinic, but the difference was not significant $(\mathrm{p}=0.207)$ (Table 4). In the preoperative period, patients who received regular nutrition developed less IPI than patients who required additional nutritional support (Table 3) $(\mathrm{p}=0.007)$, and the duration of the surgery was also shorter in patients who received regular nutrition $(\mathrm{p}=0.001)$ (Table 4$)$

In patients with pre-operative albumin levels below $3.5 \mathrm{~g} / \mathrm{dL}$, IPI developed more than those with albumin levels within the normal range (3.5-5.5 g/dL), and the difference was significant $(\mathrm{p}=0.015)$. In addition, no relationship was found between low albumin level and the duration of the surgery $(\mathrm{p}=0.861)$. Those with $\mathrm{Hb}$ level $<13.5 \mathrm{~g} / \mathrm{dL}$ had more IPI than those with $\mathrm{Hb}$ level 13.6-17.7 g/dL, but the difference was not statistically significant ( $\mathrm{p}=0.213)$, (Tables 3 and 4). There was no statistically significant difference between blood pressure and IPI $(\mathrm{p}=0.054)$. When the relationship between the positions assigned to the patients during surgery and IPI was examined, the patients with the supine position had higher IPI. However, this difference was not statistically significant $(\mathrm{p}=0.656)$ (Tables 3 and 4).

Table 4 contains the mean duration of surgery and multivariate analysis results according to some characteristics of the patients. The duration of the surgery was longer in patients with IPI $(246.70 \pm 145.58)$ than those without IPI $(166.00 \pm 88.14)$ and the difference was statistically significant $(\mathrm{p}=0.002)$. Multivariate analysis showed that each one hour extension of the duration of surgery increased the risk of IPI by 1.007 times.

It was observed that the mean BRAT score of the patients in the study was not high. According to the BRAT mean score, it was determined that $24.2 \%$ of the patients had a medium (18.434 \pm 6.621 points) risk of IPI, and $75.8 \%$ had a very low risk of IPI (20.243 \pm 3.954 points). The difference between the mean scores was statistically significant $(\mathrm{p}=0.035)$. The difference between the mean scores was statistically significant $(\mathrm{p}=0.035)$. Each category point change in the BRAT score indicated a 0.8fold risk for IPI.

According to the multivariate analysis, the risk of IPI was 2.4 times higher in patients who needed to take additional nutrition and had low albumin levels ( $\mathrm{p}=0.038 ; 0.043$, respectively). 
Table 2. Intraoperative pressure injury (IPI) by some sociodemographic characteristics ( $\mathrm{n=170)}$

\begin{tabular}{|c|c|c|c|c|c|}
\hline Characteristics & $\begin{array}{l}\text { IPI (+) } \\
\text { n (\%) }\end{array}$ & $\begin{array}{l}\text { IPI (-) } \\
\text { n (\%) }\end{array}$ & $\begin{array}{l}\text { Total } \\
\text { n (\%) }\end{array}$ & Test & $\mathrm{p}$ value \\
\hline \multicolumn{6}{|l|}{ Age } \\
\hline $29-39$ & $8(28.6)$ & $20(71.4)$ & $28(100)$ & \multirow{2}{*}{0.558} & \multirow{2}{*}{0.906} \\
\hline $40-50$ & $7(21.2)$ & $26(78.8)$ & $33(100)$ & & \\
\hline \multicolumn{6}{|l|}{ Gender } \\
\hline Female & $21(22.1)$ & 74 (77.9) & $95(100)$ & \multirow{3}{*}{0.476} & \multirow{3}{*}{0.304} \\
\hline Male & $20(26.7)$ & $55(73.3)$ & $75(100)$ & & \\
\hline Total & $41(24.2)$ & $129(75.8)$ & $170(100)$ & & \\
\hline
\end{tabular}

Table 3. Intraoperative pressure injury (IPI) by some clinical characteristics $(n=170)$

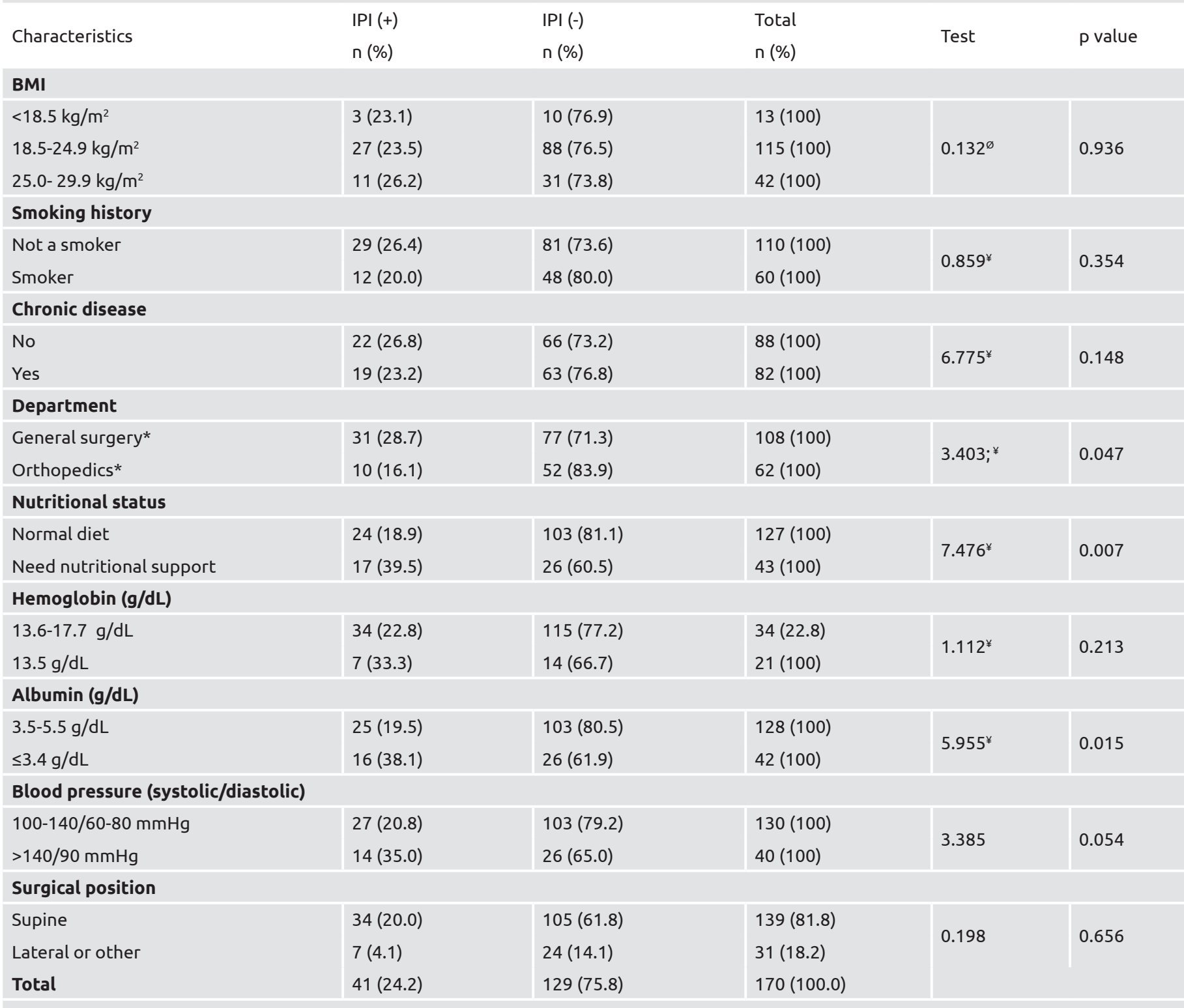

$\varnothing$ : Kruskal-Wallis chi-square test, ¥: Pearson chi-square test, BMI: Body mass index, IPI: Intraoperative pressure injury 
Table 4. Mean surgery duration by some important characteristics of the patients, multivariate analysis results



*Independent t-test, *chi-square test, **Kruskal-Wallis test

According to the Braden score, 6 or less points are considered to be very high-risk, 10-12 points as high risk, 13-14 points as moderato risk, and $15-23$ as mild to no risk in terms of development of pressure injury, SD: Standard deviation, BMI: Body mass index

\section{Discussion}

Surgical patients may have some sociodemographic and clinical factors preoperatively that may contribute to pressure-related tissue injury. Among the sociodemographic characteristics, it has been suggested that as age increases, it may pose a risk for IPI (32-34). Age was not a risk factor for IPI in the presented study. This might be due to the fact that the mean age of the patient group represented a younger group.

The relationship of gender with pressure injury is controversial in researches. However, there are studies showing women at higher risk (15). In the present study, longer surgery duration in men compared to women might have a role in the higher incidence of IPI in male patients.

It is argued that longer surgery duration and increased BMI may be related. It is suggested that the adipose tissue increases the extent of surgical intervention and with the presence of chronic diseases in which tissue nutrition is impaired, they may prolong the surgery duration (34-36). Conversely, low BMI has been shown to leave soft tissue vulnerable to pressure (8). In the study presented, there was no relationship between IPI and BMI and presence of chronic disease. The reason for this might be that the majority of the patients had a normal BMI. The number of those with low or high BMI was very small and their surgery duration was shorter. It could be concluded that the size of the surgery of the patients was decisive here.

In the literature, direct effect of the clinics where patients are hospitalized on IPI has not been shown. It has been argued that the characteristics of patients hospitalized in clinics may play a role in IPI $(24,32,37)$. Some studies suggest that patients of general surgery clinic carry the risk of IPI because they are patients with nutritional problems $(24,38,39)$. In the presented study, IPI was higher in the patients of general surgery clinic. In this result, longer surgery duration in the patients of general surgery clinic than in orthopedic patients might have a role. However, as it is known, the duration of prosthetic surgeries is long and it should be considered that this situation may reverse for the orthopedic patients in case of sufficient sample size. Studies report that there is a direct proportion between IPI and the duration of surgery $(9,10,22)$.

$\mathrm{Hb}$ deficiency and nutritional deficiency can play an important role in the development of pressure sores $(40,41)$. In the present study, the $\mathrm{Hb}$ level was normal or close to normal, as planned surgical intervention was applied in all patients. Therefore, $\mathrm{Hb}$ level was not among the factors affecting the development of IPI. However, even if surgical intervention was planned, the 
need for additional nutrients was an important variable for the development of IPI. In addition, the need for additional nutrients was thought to be effective in longer duration of surgery in those patients. It is also reported in the literature that the diet and nutritional needs of surgical patients may be important in the development of IPI. Therefore, pre- and postoperative care protocols that shorten the fasting period have been developed $(5,22)$.

As it is known, edema occurs in tissues with a decrease in albumin level $(<3.5 \mathrm{~g} / \mathrm{dL})$ and tissue resistance to pressure decreases. Thus, the incidence of pressure injury increases $(10,32,42)$. In the present study, a strong relationship between low albumin levels and IPI, regardless of the duration of the surgery, supported this literature finding.

Studies have suggested that hypotension, tachycardia, and hypothermia may cause pressure injury by increasing peripheral resistance. The decrease in tissue oxygenation with the decrease in blood pressure and body temperature in patients under general anesthesia can also increase this risk $(3,14,20,41)$. In the presented study, the blood pressure, heart rate, respiration and body temperature values of the patients were within normal limits before surgery. No risk associated with IPI was determined.

The role of position given during surgery and position support materials used in the prevention of IPI has been shown in many studies (18,43-45). In the presented study, the majority of patients were operated in the supine position, so a comparison between positions could not be made. However, the fact that IPI occured in the sacral area and the coccyx in the study and that effective position support material could not be used showed that these injuries were related to the position. It has been reported that the position given during surgery and position support materials used during the surgery (such as gel pad, smart pad, foam support) may be determinants for the location of the pressure injury $(6,18,19,22,43)$. It is pointed out that this risk will increase exponentially for every 30 minutes after the duration of surgery exceeds two hours, and the importance of position support materials is emphasized $(10,19,22,46)$.

In the presented study, there was no patient with a low BRAT score. Because all patients were patients with planned surgery and all of them could be mobilized. However, the frequency of stage I IPI, which did not fade with pressing, was higher than the expected prevalence limit for a planned long surgical procedure. This result may be related to either the lack of preoperative pressure injury risk preparations or low specificity and sensitivity of the BRAT. Although BRAT scores in patients with IPI varied within the normal score range, they showed two conditions: First, skin diagnosis with a preoperative scale suggested that a careful nurse could detect the risky patient early. Second, as the duration of the operation increased, even if a patient's pressure injury score was low, he/she might develop a pressure injury. The literature on this subject suggests that skin evaluation should be continued for at least 48-72 hours including periods before, during and after surgery to prevent IPI in long surgical procedures $(43,41,46)$.

\section{Study Limitations}

In this study, as in many institutions, a scale specific to the evaluation of ASBI was not used. It was thought that it would be more useful to show the results of scales actively used in clinics rather than scales preferred by researchers. This scale might not be able to precisely define the effect of variables belonging to surgical stage on the results, since it could not make a clear evaluation of the surgery. Since the study included only patients of general surgery clinic and orthopedic patients, the effects of different surgical positions could not be evaluated. These two situations were the most important limitations of the study.

\section{Conclusion}

According to the data of this study, it could be concluded that IPI was a perioperative care problem that nurses should monitor carefully in planned major surgical procedures. Inadequate nutritional level, low albumin level, length of duration of surgery, change in BRAT score (even if it varied within normal limits) should be evaluated as important for IPI. Preoperative risk diagnosis and skin diagnosis of surgery nurses and operating room nurses were important for long surgical procedures. Nevertheless, BRTA should be used with caution in assessing the risk of IPI.

According to the limitations and findings of this study, a more comprehensive study with the " $3 S$ Operating Room Pressure Injury Risk Assessment Scale" was planned and presented to the institution.

\section{Acknowledgements}

The authors would like to thank all operating room nurses of the institution where the study was conducted, to Assoc. Prof. Dr. Sedat Ziyade and to the patients who took part in the study for their contribution and support to this study.

\section{Ethics}

Ethics Committee Approval: The permission was obtained from the Clinical Research Ethics Committee of the relevant University Hospital for the research (Ethics committee permission no: 05.07.2017-11968-11/160).

Informed Consent: The study was approved by the ethics committee and informed written permission was obtained from the institutions and volunteers.

Peer-review: Externally peer reviewed.

\section{Authorship Contributions}

Design: Y.Y.S., C.A., Data Collection or Processing: C.A., Analysis or Interpretation: Y.Y.S., C.A., Literature Search: Y.Y.S., C.A., Writing: Y.Y.S.

Conflict of Interest: No conflict of interest was declared by the authors.

Financial Disclosure: The authors declared that this study received no financial support. 


\section{References}

1. Kandilov AM, Coomer NM, Dalton K. The impact of hospitalacquired conditions on Medicare program payments. Medicare Medicaid Res Rev 2014;4:1-22.

2. Shafipour V, Ramezanpour E, Gorji MA, Moosazadeh M. Prevalence of postoperative pressure ulcer: A systematic review and meta-analysis. Electronic Physician 2016;8:3170-6.

3. Walton-Geer PS. Prevention of pressure ulcers in the surgical patient. AORN J 2009;89:538-48.

4. Karayurt Ö, Çelik B. Ameliyata bağlı basınç yarası ve hemşirelik bakımı. Türkiye Klinikleri Cerrahi Hastalıkları Hemşireliği-Yara ve Hemşirelik Bakımı Özel Sayısı 2017;3:176-82.

5. O'Brien DD, Shanks AM, Talsma A, Brenner PS, Ramachandran SK. Intraoperative risk factors associated with postoperative pressure ulcers in critically ill patients: a retrospective observational study. Crit Care Med 2014;42:40-7.

6. Kim JM, Lee H, Ha T, Na S.Perioperative factors associated with pressure ulcer development after major surgery. Korean J Anesthesiol 2018;71:48-56.

7. Gül Ş. Cerrahi girişim uygulanan hastalarda basınç ülseri gelişiminin önlenmesi. Hacettepe Üniversitesi Hemşirelik Fakültesi Dergisi 2014;54-61.

8. Tschannen D, Bates O, Talsma A, Guo Y. Patient-specific and surgical characteristics in the development of pressure ulcers. Am J Crit Care 2012;21:116-25.

9. Hayes RM, Spear ME, Lee SI, Krauser Lupear BE, Benoit RA, Valerio R, et al. Relationship between time in the operating room and incident pressure ulcers: a matched case-control study. Am J Med Qual 2015;30:591-7.

10. Primiano M, Friend M, McClure C, Nardi S, Fix L, Schafer M, et al. Pressure ulcer prevalence and risk factors during prolonged surgical procedures. AORN J 2011;94:555-66.

11. Katran HB. Bir cerrahi yoğun bakım ünitesinde bası yarası görülme sıklığı ve bası yarası gelişimini etkileyen risk faktörlerinin irdelenmesi. JAREN 2015;1:8-14.

12. Chen HL, Chen XY, Wu J. Theincidenceofpressure ulcers in surgical patients of the last 5 years: a systematic review. Wounds 2012;24:234-41.

13. Spruce L, Van Wicklin SA. Back to basics: positioning the patient. AORN J 2014;100:298-305.

14. Fu Shaw L, Chang, PC, Lee JF, Kung HY, Tung TH. Incidence and predicted risk factors of pressure ulcers in surgical patients: experience at a medical center in Taipei, Taiwan. BioMed Research International 2014;1-10.

15. Tan A. Cerrahi Yoğun bakım hastalarında basınç yarası gelişme riski. İnönü Üniversitesi Sağlık Bilimleri Enstitüsü, Yüksek Lisans tezi (yayınlanmamış) 2015. http://abakus.inonu.edu.tr/xmlui/bitstream/ handle/11616/5085/Tez\%20Dosyası.pdf?sequence=1 \&isAllowed=y

16. Mutlu S. Açık kalp ameliyatı uygulanan hastalarda basınç yaralanması oluşumunu etkileyen faktörlerin incelenmesi. DEÜ Sağlık Bilimleri Enstitüsü, Yüksek lisans tezi (yayınlanmamış) 2012.

17. Uzun O, Tan M. A. A prospective, descriptive pressure ulcer risk factor and prevalence study at a university hospital in Turkey. Ostomy Wound Manage 2007;53:44-56.
18. Beckett AE. Are we doing enough to prevent patient injury caused by positioning for surgery?. J Perioper Pract 2010;20:26-9.

19. Shen WQ, Chen HL, Xu YH, Zhang Q, Wu J. The relationship between length of surgery and the incidence of pressure ulcers in cardiovascular surgical patients: A retrospective study. Adv Skin Wound Care 2015;28:444-50.

20. Cherry C, Moss J. Best practices for preventing hospitalacquiredpressureinjuriesinsurgicalpatients. Can Oper Room Nurs J 2011;29:22-6.

21. He W, Liu P, Chen HL. The Braden Scale cannot be used alone for assessing pressure ulcer risk in surgical patients: a metaanalysis. Ostomy Wound Manage. 2012;58:34-40.

22. Nilsson UG. Intraoperative positioning of patients under general anesthesia and the risk of postoperative pain and pressure ulcers. J Perianesth Nurs 2013;28:137-43.

23. Günes ÜY, Efteli E. Predictivevalidityandreliabilityof the Turkish version of the risk assessment pressure sore scale in intensive care patients: results of a prospective study. Ostomy Wound Manage 2015;61:58-62.

24. RaoAD, PrestonAM, StraussR, StammR, ZalmanDC. Risk factors associated with pressure ulcer formation in critically Ill cardiac surgery patients: A systematic review. J Wound Ostomy Continence Nurs 2016;43:242-7.

25. Spruce L. Back to basics: preventing perioperative pressure injuries. AORN J 2017;105:92-9.

26. ChenHL, ShenWQ, LiuP, LiuK. Lengthofsurgery and pressure ulcers risk in cardiovascular surgical patients: a dose- responsemeta-analysis. Int Wound J 2017;14:864-9.

27. Tanrıverdi F, Dikmen Y. Yoğun bakım hastalarında basınç yaraları: Risk faktörleri ve önlemler. J Hum Rhythm 2017;3:177-82.

28. Bergstrom N, Braden BJ, Laguzza A, Holman V. The Braden scale for predicting pressure sore risk. Nurs Res 1987;36:205-10.

29. Pınar R, Oğuz S. Norton ve braden bası yarası değerlendirme ölçeklerinin yatağa bağımlı aynı hasta grubunda güvenirlik ve geçerliğinin sınanması: Uluslararası Katılımlı VI. Ulusal Hemşirelik Kongresi, Kongre Kitab1, Ankara, 1998;172-5.

30. Chan WS, Pang SM, Kwong EW. Assessing predictive validity of the modified Braden scale for prediction of pressure ulcer risk of orthopaedic patients in an acute care setting. J Clin Nurs 2009; 18:1565-73.

31. Gao XL, Hu JJ, Ma Q, Wu HY, Wang ZY, Li TT, et al. Design and research on reliability-validity for $3 S$ intraoperative risk assessment scale of pressure sore. J Huazhong Univ Sci Technolog Med Sci 2015;35:291-4.

32. Lindgren M, Unosson M, Krantz AM, Ek AC. Pressure ulcer risk factors in patients undergoing surgery. J Adv Nurs 2005;50:605-12.

33. Efteli EÜ, Güneş Ü. Basınç yaralanması gelişiminde perfüzyon değerlerinin etkisi. Anadolu Hemşirelik ve Sağlık Bilimleri Dergisi 2014;17:3.

34. Chen HL, Chen XY, Wu J. Theincidenceofpressure ulcers in surgical patients of the last 5 years: a systematic review. Wounds 2012;24:234-41. 
35. Lowe JR. Skinintegrityincriticallyillobesepatients. Critical Care Nursing Clinics 2009;21:311-22.

36. Chaboyer W, Gillespie BM. Understanding nurses' views on a pressure ulcer prevention care bundle: a first step towards successful implementation. J Clin Nurs 2014;23:3415-23.

37. Agrawal K, Chauhan N. Pressure ulcers: Back to the basics. Indian J Plast Surg 2012;45:244-54.

38. Dolgun E, Yavuz M. Aşırı şişmanlık cerrahisinde hemşirelik bakımı. Maltepe Üniversitesi Hemşirelik Bilim ve Sanatı Dergisi 2009;3:8592.

39. Karadağ M, Gümüşkaya N. The incidence of pressure ulcer in surgical patients: a sample in Turkey. J Clin Nurs 2006;15:413-21.

40. Dumlu EG, Bozkurt B, Tokaç M, Kıyak G, Özkardeş AB, Yalçın S, et al. Cerrahi hastalarda malnütrisyon ve beslenme desteği. Ankara Medical Journal 2013;13:33-7.

41. Inan DG, Otunç G. Pressure ulcer prevalence in Turkey: a sample from a university hospital. J Wound Ostomy Continence Nurs 2012;39:409-13.
42. Webster J, Lister C, Corry J, Holland M, Coleman K, Marquart L. Incidenceand risk factors for surgically acquired pressure ulcers. J Wound Ostomy Continence Nurs 2015;42:138-44.

43. Lumbley JL, Ali SA, TchokouaniL S. Retrospective review of predisposing factors for intraoperative pressure ulcer development. J Clin Anesth 2014;26:368-74.

44. Adedeji R, Oragui E, Khan W, Maruthainar N. The importanceofcorrectpatientpositioningintheatresandimplicationsof mal-positioning. J Perioper Pract 2010;20:143-7.

45. Black J, Fawcett D, Scott S. Ten top tips: preventing pressure ulcers in the surgical patient. Wounds Int J 2014;5:14-8.

46. Aloweni F, Ang SY, Fook-Chong S, Agus N, Yong P, Goh MM, et al. A prediction tool for hospital-acquired pressure ulcers among surgical patients: Surgical pressure ulcer risk score. Int Wound J 2019;16:16475. 